\title{
Notes
}

\section{A Norm-Based Remedial Model for Underinclusive Statutes}

\author{
Evan H. Caminker
}

After declaring that a statutory provision which distributes benefits to or imposes burdens on some persons but not others violates a constitutional equal treatment requirement, courts must decide whether to remedy the infirmity by invalidating the' provision or by expanding its coverage. Courts currently approach this remedial enterprise as if no substantive constitutional values guide the choice between nullification and extension; they implement whichever remedy best furthers the legislative purposes animating the underlying statutory scheme.

This current remedial model is impoverished: its singular focus on legislative policy judgments ignores the potential relevance of substantive constitutional norms to the remedial decision. The doctrinal mandate of equal treatment does not itself dictate a preference for extension or nullification. But the Constitution embodies numerous extra-doctrinal substantive norms generally beyond the institutional power of courts to enforce because of competing structural values; these "inchoate" substantive norms often do assert a preference between the two remedies. These inchoate norms, rather than legislative policy preferences, should guide a court's extension/nullification decision. Such a norm-based remedial model would structure a judicial-legislative colloquy encouraging greater conformity between legislative policies and substantive constitutional values while maintaining proper respect for legislative authority in our scheme of separated powers.

After examining the Supreme Court's current remedial model, I explore the genesis of inchoate constitutional norms, focusing on equal treatment problems in First Amendment and sexual equality jurisprudence to demonstrate how such inchoate norms can dictate a constitutional preference for extension or nullification in specific situations. I then outline a 
norm-based remedial model according to which courts should incorporate such constitutional preferences into the remediation process.

\section{The Current Remedial Model.}

Laws that distribute benefits or burdens in an underinclusive fashion may violate a doctrinal requirement of equal treatment, derived from the equal protection clause or some other constitutional source, which mandates that all individuals deemed similarly situated be allotted by government the same specified benefit or burden. ${ }^{1}$ The wrong of unequal treatment can be remedied by any level of equal provision of the specified benefit: "Equality itself is as well pleased by graveyards as by vineyards."2 Hence, where a statute is found underinclusive "there exist two remedial alternatives: a court may either declare it a nullity and order that its benefits not extend to the class that the legislature intended to benefit, or it may extend the coverage of the statute to include those who are aggrieved by exclusion." 3 The Supreme Court usually has opted for creating

1. Although I focus solely on legislative actions, my analysis pertains equally to underinclusive actions taken by all federal and state governmental officials.

2. D. RAE, EQualities 129 (1981).

3. Welsh v. United States, 398 U.S. 333, 361 (1970) (Harlan, J., concurring); accord, Heckler v. Mathews, 465 U.S. 728, 738 (1984); Iowa-Des Moines Nat'l Bank v. Bennett, 284 U.S. 239, 247 (1931).

Though choosing between extension and nullification is often characterized as a process of "statutory interpretation," Miller, Constitutional Remedies for Underinclusive Statutes: A Critical Appraisal of Heckler v. Mathews, 20 HARv. C.R.-C.L. L. REv. 79, 86 (1985), this characterization is dangerously misleading, as it masks the remedial nature of the judicial undertaking. This mischaracterization may stem from misapplication of an analogy frequently drawn between the extension/nullification decision and the more traditional question of severability, where a court finding one part of a statutory scheme unconstitutional on non-equality grounds must choose whether to sever it and continue to enforce the remaining part or to invalidate the entire scheme.

The severability decision embraces three discrete conceptual stages: (1) rights declaration concluding that a provision exceeds the legislature's authority to enact or violates constitutional guarantees; (2) implementing a remedy by enjoining the operation of that provision; and (3) statutory construction to determine whether the remaining provisions should stand as law without the enjoined provision. See Alaska Airlines, Inc. v. Donovan, 766 F.2d 1550, 1555 (D.C. Cir. 1985) (constitutional right and remedy already fully addressed before court engages in severability inquiry which then "reduces to a matter of statutory interpretation"), cert. granted sub nom. Alaska Airlines, Inc. v. Brock, 106 S. Ct. 1259 (1986); Stern, Separability and Separability Clauses in the Supreme Court, 51 HARv. L. REv. 76, 114-15 (1937) (court first "remed[ies] substantive constitutional defects in statutes" and then addresses question of severability). The extension/nullification decision has the same logical structure: first the court declares the discrimination (either within one or between two provisions) unconstitutional; then it implements a particular remedy by choosing extension or nullification; and finally it faces the question analogous to severability, which is whether the rest of the statutory scheme (if any) can function coherently with the discrimination redressed.

Hence, the court's second step-choosing between extension and nullification-is properly characterized as remediation, not statutory construction. Consistent with this understanding, a court does not actually effect an extension by "amending" the statute; rather, it enjoins officials to distribute benefits as if the statute's coverage were enlarged. See, e.g., Westcott v. Califano, 460 F. Supp. 737, 754 (D. Mass. 1978) (declaring statute disbursing unemployment benefits unconstitutional insofar as it discriminated against unemployed mothers and ordering administrator not to deny benefits in future on account of sex). Furthermore, a court's choice between extension and nullification is not constrained 
vineyards in such situations, declaring that "ordinarily 'extension [of benefits,] rather than nullification, is the proper course." "44 Yet the Court also has "often recognized that the victims of a discriminatory government program may be remedied by an end to preferential treatment for others."

Whether a court creates graveyards or vineyards, its choice is not final. Where courts nullify provisions, legislatures can respond by enacting extended and hence constitutional versions; where courts extend provisions, legislatures can subsequently repeal them. Thus, the legislature retains final control over the extension/nullification decision. ${ }^{6}$

Still, a court must implement a remedy which acts as a "starting point" for legislative review. ${ }^{7}$ Since the doctrinal right to equal treatment itself asserts no constitutional preference between extension and nullification, courts must look elsewhere for a rule of decision. ${ }^{8}$ The current remedial

by the particular manner in which a statutory text prescribes unequal treatment. Court-ordered relief often coincides with a "rewording" rather than "deletion" of an offending clause, e.g., extending benefits granted by statute to "males" to all persons. See Note, Extension versus Invalidation of Underinclusive Statutes: A Remedial Alternative, 12 Colum. J.L. \& Soc. Pross. 115, 120-22 (1975) (noting tendency of courts to "add language" to statutes).

4. Heckler v. Mathews, 465 U.S. 728, 739 n.5 (1984) (citation omitted). See, e.g., Califano v. Westcott, 443 U.S. 76 (1979) (extending social security benefits to needy children with unemployed mothers as well as those with unemployed fathers); Califano v. Goldfarb, 430 U.S. 199 (1977) (extending social security survivors' benefits to independent widowers as well as dependent widowers and all widows); Weinberger v. Wiesenfeld, 420 U.S. 636 (1975) (extending survivors' benefits to cover widowers as well as widows).

5. Hechler, 465 U.S. at 740 n.8. See, e.g., id. at 739 n.5 (nullification of benefits would be appropriate remedy if sex-based classification were held invalid).

In theory a court need not equalize benefits through absolute nullification or extension; it can instead adopt an intermediate remedial position, for example, by extending coverage of a benefit but at the same time reducing its size. Yet the Court has consistently rejected this option, perhaps to avoid troublesome line-drawing. In Westcott the Court refused to remedy an underinclusive federal law providing unemployment benefits only to men by ordering disbursement to all "principal wageearners" despite its recognition that the enacting Congress would have preferred this remedy to either straightforward extension or nullification. 443 U.S. at 90-91. Instead of "restructuring . . . the Act," id. at 92, the Court implemented "the simplest and most equitable" remedy by ordering the benefits extended in full to unemployed women as well. Id. at 93.

6. Of course, legislative "reversal" of a court's remedial disposition must overcome the many hurdles inherent in the legislative process that create inertia favoring maintenance of the status quo. Thus, a court's decision can strongly influence the ultimate resolution of the extension/nullification dilemma. See G. Calabresi, A Common Law for the Age of Statutes 4 (1982) (inertia attaches to common law and statutory interpretation); Kanowitz, "Benign" Sex Discrimination: Its Troubles and Their Cure, 31 HAstings L.J. 1379, 1422-24 (1980) (inertia attaches to court's remedial disposition of constitutional challenge).

7. For an intriguing treatment of courts as setters of starting points for statutory modification by subsequent legislatures, see G. CALABRESI, supra note 6 .

8. In some situations, the standard of future treatment for one class is unalterably fixed and hence the court can provide prospective relief equalizing benefits or burdens in a single direction only. See, e.g., Taylor v. Louisiana, 419 U.S. 522 (1975) (because jury trials are guaranteed by Sixth Amendment, court invalidating statute excluding non-volunteer women from jury venire can prospectively equalize treatment only by ordering both women and men included).

On occasion, a court wishing to award a plaintiff retrospective as well as prospective relief might also have only one remedial option. For example, suppose a plaintiff suffered a burden not imposed on similarly situated people under circumstances precluding the court from retroactively expanding the burden's coverage. Since the court must take the treatment of the other people as fixed, it must 
model requires courts to defer to the legislative branch and choose the option that they believe the enacting legislature would have preferred had it known that its intended discrimination was unlawful. ${ }^{\circ}$ If the legislature in fact considered the potential invalidation of its discriminatory scheme and enacted a severability clause pertaining directly to the allocative provision in question, the clause can provide a court with evidence of the legislature's actual remedial intent. ${ }^{10}$ However, legislatures very rarely enact specific severability clauses; indeed, most probably never consider the possibility that courts will invalidate a particular provision and hence do not deliberate about a "second choice" remedy. ${ }^{11}$ In such cases a court must attempt to identify the policies motivating the law's initial adoption and second-guess the relative priority that the legislature attributed to competing concerns in order to "decide whether it more nearly accords with Congress' wishes to eliminate its policy altogether or extend it in

equalize the plaintiff's treatment to theirs. See, e.g., Welsh v. United States, 398 U.S. 333, 362 (1970) (Harlan, J., concurring) (because Court cannot retroactively order nullification of underinclusive exemption to draft statute, Court must overturn criminal conviction of draft evader or he will "go remediless"). For discussion of factors relevant to a court's decision to provide retrospective relief, see Ginsburg, Some Thoughts on Judicial Authority to Repair Unconstitutional Legislation, 28 CLEv. ST. L. REv. 301, 322-24 (1979).

9. See, e.g., Heckler, 465 U.S. at 739 n.5 (noting that enacting Congress "clearly expressed its preference for nullification"); Westcott, 443 U.S. at 94 (opinion of Powell, J.) (court "should not use its remedial powers to circumvent the intent of the legislature"); Ginsburg, supra note 8, at 316-18; Kanowitz, supra note 6, at 1413-14; Miller, supra note 3, at 82-83.

By implementing the presumed remedial will of the enacting legislature the court does not necessarily further the current legislature's will, simply because the former may not reflect the latter. First, changes since a provision's enactment in the legislature's political composition, its general policy concerns, and social and economic conditions will alter remedial preferences, with divergence likely to increase with the time interval. Second, the discriminatory provision's enactment itself might affect remedial preferences. For example, even an underinclusive provision of benefits will generate reliance interests; hence, a legislature preferring to distribute no benefits rather than equalized benefits prior to the provision's enactment might prefer extension over nullification after enactment and invalidation in order not to frustrate expectations. There is, therefore, no predictable correlation between the court's disposition under the current remedial model and the current legislature's remedial will.

10. The Supreme Court in Heckler held that a severability clause which referred specifically to a discriminatory provision and which urged reduction in benefits upon judicial invalidation provided dispositive evidence of the legislature's remedial intent and "would prevent a court from redressing this inequality by increasing the benefits payable." Heckler, 465 U.S. at 738.

Legislatures commonly adopt general severability clauses, which attach to entire statutory schemes as opposed to specific provisions. Such general clauses, which urge courts to elide those provisions of a statutory scheme found unconstitutional rather than to invalidate the entire scheme, are not similarly probative of the legislature's remedial intent. Relevant to the third conceptual stage in the adjudicative process, see supra note 3 , such clauses counsel against invalidating an entire benefits program merely because one of its many provisions is underinclusive. However, they provide no direction to courts seeking to remedy the underinclusive provision: there are two ways of restoring equal treatment and hence two ways of "saving" the entire program. See Nat"l Life Ins. Co. v. United States, 277 U.S. 508, 535 (1928) (Brandeis, J., dissenting) (general severability clause "gives no light as to which course Congress would prefer" to remedy underinclusion). The Supreme Court has at most acknowledged a general severability clause as one of several probative indicia of remedial intent. See, e.g., Westcott, 443 U.S. at 90 (considering general severability clause as one relevant factor).

11. See Miller, supra note 3, at 90; of. Sandalow, Judicial Protection of Minorities, $75 \mathrm{MICH}$. L. REv. 1162, 1188 (1977) (discussing structural reasons for Congress' "inability to consider carefully many of the constitutional issues raised by legislation"). 
order to render what Congress plainly did intend, constitutional."12 Courts often have looked to purportedly probative circumstantial evidence of the enacting legislature's intent to render the inquiry more manageable. In addition to gauging the "intensity of commitment to the residual policy and consider[ing] the degree of potential disruption of the statutory scheme that would occur by extension as opposed to abrogation," ${ }^{\mathbf{1 3}}$ courts have considered some or all of the following factors relevant to the inquiry: the relative size of the class originally included compared to that originally excluded; the cost of extension of benefits to the government or private provider; whether the statute allocates a benefit or a burden; and whether a burden is criminal or civil in nature. ${ }^{14}$

While the Supreme Court has never articulated a justification for embracing this remedial model, ${ }^{15}$ its practice of legislative deference seems

12. Welsh v. United States, 398 U.S. 333, 355-56 (1970) (Harlan, J., concurring).

13. Id. at 365.

14. See, e.g., Brown, Emerson, Falk \& Freedman, The Equal Rights Amendment: A Constitutional Basis for Equal Rights for Women, 80 YALE L.J. 871, 914-17 (1971); Ginsburg, supra note 8, at 318-21; Note, supra note 3, at 125-43; cf. Cort v. Ash, 422 U.S. 66, 78 (1975) (identifying four factors as criteria for discerning Congress' intent to create private statutory rights of action).

These factors' probative value rests more on assumptions about general legislative behavior drawn from observations over time than on the presumption that a particular enacting legislature would have focused its attention on them in forming a remedial intent. $C f$. California v. Sierra Club, 451 U.S. 287, 301 (1981) (Stevens, J., concurring) (more appropriate when implying private statutory rights of action to analyze four Cort criteria than to guess at enacting legislature's actual intent). In fact, courts often draw upon general observations about legislative behavior even while framing the inquiry in terms of the enacting legislature's intent. For example, while recommending in Welsh that an exemption from induction granted to religious conscientious objectors be extended to exempt nonreligious objectors as well, Justice Harlan appealed not to the legislature's policy concerns embodied in the draft statute itself but to a "longstanding tradition ... [ [with] roots so deeply embedded in history" of recognizing exemption for conscientious objectors from participating in war as an "important value." Welsh, 398 U.S. at 365-66 (Harlan, J., concurring).

Indeed, courts occasionally have appealed to constitutional due process values when attributing to enacting legislatures a desire not to extend prospectively the coverage of criminal laws. Even where particular defendants had fair notice that their conduct was covered by an underinclusive criminal statute such that its extension to cover others would not violate anyone's due process rights, $c f$. Marks v. United States, 430 U.S. 188, 192 (1977) (judicial enlargement of criminal statute without fair notice violates due process), courts still are reluctant to extend criminal burdens prospectively. See, e.g., People v. Yocum, 31 Ill.App.3d 586, 335 N.E.3d 183 (1975); Commonwealth v. MacKenzie, 368 Mass. 613, 334 N.E.2d 613 (1975); Tatro v. State, 372 So.2d 283 (Miss. 1979); Note, The Effect of an Unconstitutional Exception Clause Upon the Remainder of a Statute, 55 HARV. L. REv. 1030, 1031 (1942) ("courts have usually refused to extend the scope of a criminal statute by [eliding an exception clause] since to do so would create new crimes").

Hence, though courts generally articulate a concern for the presumed intent of the enacting legislature, in practice they often construct that intent by adverting to a broader range of sources of legislative and even constitutional interests. Cf. Califano v. Westcott, 443 U.S. 76, 90 (1979) (referring to "equitable considerations" supporting remedial choice).

15. Where the underinclusive law was of state origin, the Supreme Court frequently has avoided the remedial issue by remanding the decision to a state court when permitted by the case's procedural posture. The remand vindicates federalism principles, since determining a state legislature's policy preferences "may be more appropriately left for adjudication" by the state judiciary. Skinner v. Oklahoma, 316 U.S. 535, 543 (1942). See, e.g., Orr v. Orr, 440 U.S. 268 (1979); Stanton v. Stanton,
421 U.S. 7 (1975).

When an underinclusive state law is challenged in federal court or where the underinclusive law is 
best defended by appeal to a particular view of separation of powers challenging the legitimacy of judicial policymaking when courts fashion remedies. ${ }^{18}$ Because the constitutional equal treatment requirement itself is indifferent between extension and nullification, a court is thought to discharge fully its obligation to secure constitutional values against legislative infringement simply by mandating the equal provision of benefits or burdens at any level. Since presumably no constitutional values inform the court's choice of a particular level, the court must rely on policy considerations, which are thought peculiarly the institutional province of legislatures. ${ }^{17}$ Lacking direction from a constitutional text, the court can avoid policymaking only by drawing guidance from the available statutory text and selecting the remedy it believes the legislature would prefer. $^{18}$

of federal origin, the Supreme and federal courts must select a remedy themselves. But even in the few cases where it has done this, the Supreme Court has not discussed, let alone justified, its basis for choice. See, e.g., Jiminez v. Weinberger, 417 U.S. 628, 637-38 (1974) (extending Social Security benefits to originally excluded class of illegitimate children); Frontiero v. Richardson, 411 U.S. 677, 691 \& n.25 (1973) (plurality opinion) (extending military benefits to servicewomen with financially independent husbands).

16. For an explication of this view, see Fletcher, The Discretionary Constitution: Institutional Remedies and Judicial Legitimacy, 91 YAL.E L.J. 635 (1982) (arguing judicial remedial discretion in structural reform litigation is legitimate only where political process malfunctions).

17. See Ginsburg, supra note 8, at 317 (a court "concludes its essentially judicial business" by declaring a statute unconstitutional and mandating the constitutionally adequate remedy of equal treatment; "the remaining task [of choosing between extension and nullification] is essentially legislative"); Fletcher, supra note 16, at 693 (court choosing among different remedial decrees, each adequate to vindicate doctrinal rights, is "taking over a political function").

18. This explanation of legislative deference presumes that the judiciary is the governmental branch responsible for fashioning remedies for constitutional violations, but that courts choose to execute this task by incorporating by reference the enacting legislature's presumed policy judgments. Another explanation of this practice seems plausible, however: one might presume instead that the legislative branch is primarily responsible for devising remedies. Given this second premise, a court facing the extension/nullification decision is in essence acting as a "short-term surrogate for the legislature," Ginsburg, supra note 8 , at 317 , and hence must defer to legislative intent for this reason.

Since legislative deference seems appropriate according to either premise, the Supreme Court has not had to embrace explicitly one view over the other. However, the Court's language strongly supports the view that the responsibility for fashioning a remedy properly lies with the judiciary. See, e.g., Heckler, 465 U.S. at $739 \mathrm{n} .5$ ("court should not, of course, "use its remedial powers to circumvent the intent of the legislature' ") (emphasis added and citation omitted); Westcott, 443 U.S. at 91 (remedial choice is within "constitutional competence of a federal district court"); Welsh, 398 U.S. at 364 (Harlan, J., concurring) (discussing judicial "exercise of discretion in determining whether a legislative policy should be repaired or abandoned"). Justice Harlan has employed much clearer language supporting the premise of judicial responsibility in other remedial contexts. See Bivens v. Six Unknown Named Agents of Fed. Bureau of Narcotics, 403 U.S. 388, 405 n.6 (1971) (Harlan, J., concurring) ("description of the remedy [for a constitutional violation] as 'inferred' cannot, of course, be intended to assimilate the judicial decision to accord such a remedy to any process of statutory construction [but] . . . can only bear on the reasons offered to explain a judicial decision [about relief]") (emphasis added).

Moreover, the case for viewing the decision as primarily the judiciary's institutional responsibility becomes compelling once it is recognized that the decision often implicates substantive constitutional values. See Hill, Constitutional Remedies, 69 Colum. L. Rev. 1109, 1112-13 (1969) (judiciary has primary responsibility for fashioning remedies to vindicate constitutional rights); see infra text accompanying notes $70-72$.

Extensive analysis of the appropriate constitutional allocation of remedial powers between the judicial and legislative branches in different contexts is beyond my capacity here. It must suffice to observe 


\section{Inchoate Constitutional Norms and the Fallacy of FungIBLE REMEDIES}

The current intent-based model is impoverished: it fails to acknowledge and incorporate the entire set of substantive constitutional norms relevant to the remedial enterprise. This failure undermines the appeal of legislative deference in this remedial context.

The current model correctly assumes that both extension and nullification adequately satisfy a doctrinal right to equal treatment: neither an expanded nor contracted provision of benefits by the legislature would violate this doctrinal right. However, the model's conclusion that therefore no substantive constitutional norms exist to guide a court's remedial decision is flawed. This conclusion assumes that the scope of a substantive constitutional norm always coincides with the scope of its judicial enforcement through the invalidation of legislative actions. But this second assumption is false: a court's refusal to invalidate a legislative allocation does not necessarily mean that the allocation comports fully with constitutional norms. Indeed, the Supreme Gourt has long recognized in other contexts that the Constitution's binding authority exists autonomously from, and is broader than, its enforcement through adjudication: "The Constitution has many commands that are not enforceable by courts because they clearly fall outside the conditions and purposes that circumscribe judicial action."19 For both conceptual and institutional reasons, the doctrinal rights designed and invoked by courts to invalidate nonconforming legislation rarely exhaust the full scope of their underlying constitutional norms, generating a norm-doctrine gap.

First, many constitutional norms (as identified by text or implied by structure) support a wide range of meanings. Such a norm can guide the resolution of actual controversies only after courts ascribe to it a more determinate meaning by embracing a particular conception of the abstract norm. ${ }^{20}$ For example, the abstract notion of equality embedded within the equal protection clause generates at least two plausible conceptions: equality of treatment and equality of outcome. ${ }^{21}$ Having embraced one conception, courts will enforce only those legal claims generated by the chosen

that the norm-based remedial model developed herein fits comfortably within a wide range of answers to this question, as it incorporates distinctive contributions from both branches.

19. Colegrove v. Green, 328 U.S. 549, 556 (1946) (discussing judicial nonenforcement of specific duties imposed by Constitution on legislative and executive branches, e.g. to execute laws faithfully).

20. Professor Fiss terms these chosen conceptions "mediating principles," constructed and employed by courts to "give meaning and content to an ideal embodied in the text." Fiss, Groups and the Equal Protection Clause, 5 PHIL. \& PUB. AfF. 107, 107 (1976). For discussion of the analogous concept/conception distinction, see R. Dworkin, TAkING RIGHTS SERIousLy 134-35 (1977); J. RAwLS, A THEoRY of Justice 3-6 (1971); Sager, Fair Measure: The Legal Status of Underenforced Constitutional Norms, 91 HARv. L. REv. 1212, 1213-14 (1978).

21. See Fiss, supra note 20 , at 176. 
conception and not those generated solely by the rejected conceptions. Thus if the equal treatment conception of equality is chosen, an individual who is treated equally has no legal complaint simply because she ends up less well off than others. Next, courts must construct even more specific and elaborate legal doctrines with which to translate the chosen conception into a workable standard for the resolution of concrete cases. ${ }^{22}$ A gap thus is created between the norm and its doctrinal manifestation: manageable doctrines identify as unconstitutional only a subset of legislative actions which contravene the norm motivating the doctrine. Current equal protection doctrine, for example, limits strict judicial scrutiny to discriminations based upon suspect classifications or infringing upon fundamental rights. Such cases represent "only a small part of the universe of plausible claims of unequal and unjust treatment by government." 23

Second, judicial fealty to structural separation of powers norms limits the acceptable scope and nature of court enforcement of substantive norms, discouraging the choice of broad conceptions and the deployment of expansive legal doctrines in specific cases. Our constitutional democracy necessarily grants the politically accountable legislature great discretion to regulate and allocate resources for the common good; courts cannot enforce substantive normative conceptions which will constrict this legislative domain too severely. ${ }^{24}$ More specifically, courts' ability to enforce constitutional norms to their full conceptual contours is constrained by the current state action doctrine, which precludes judicial enforcement of affirmative rights by declaring that only government action and not inaction can violate constitutional guarantees; ${ }^{25}$ by legislative control of the purse, which weighs heavily against judicial decrees permanently expanding and reordering priorities for legislative expenditures, ${ }^{26}$ and by concerns for judicial competence such as justiciability, which warrant deference to other branches better institutionally suited to make certain kinds of judgments. ${ }^{27}$

22. See Michelman, Property, Utility, and Fairness: Comments on the Ethical Foundations of "Just Compensation" Law, 80 HARv. L. REv. 1165, 1250 (1967) (courts "seek an articulate doctrinal packaging for all judgments"); Sager, supra note 20, at 1214.

23. Sager, supra note 20 , at 1216.

24. See Unger, The Critical Legal Studies Movement, 96 HARv. L. REv. 561, 604 (1983) (overly extensive judicial enforcement of equality norm is "incompatible with the [democratic] constitutional organization of the state").

25. See The Civil Rights Cases, 109 U.S. 3, 17-18 (1883). The doctrine serves both to limit judicial authority to secure realms of discretion for state and federal legislatures and to protect liberty and autonomy values that might be threatened by judicial enforcement of constitutional rights against private actors. See L. Tribe, American Constrututional Law 1149-50 (1978).

26. See Frug, The Judicial Power of the Purse, 126 U. PA. L. REv. 715 (1978). This structural norm may itself reflect in part an underlying substantive concern: allocating funds to serve some constitutional values may reduce those available to serve others, and courts arguably are less equipped than legislatures to measure and hence to weigh the effect of a specific norm-securing expenditure on overall norm protection.

27. For example, courts may be thought incapable of setting principled bounds on their enforce- 
Thus, for both conceptual and institutional reasons, judicial doctrines brought to bear in specific cases to invalidate legislative actions often leave unenforced the margins of substantive constitutional norms. ${ }^{28}$

Yet, though courts by definition cannot invoke these unenforced margins or "inchoate norms" to invalidate legislative allocative decisions, they should draw upon these norms for guidance when choosing how to remedy an equal treatment violation. Though the remedies of extension and nullification are both formally adequate in that they satisfy the doctrinal requirement, an inchoate norm often provides a constitutionally-grounded reason to prefer the distribution of goods or burdens flowing from one of these remedies: some distributions better promote the full realization of that norm. Hence, extension and nullification should not always be viewed as constitutionally equivalent remedies. ${ }^{29}$ The following two Sec-

ment of certain norms, especially those requiring affirmative government action. Legal claims for the enforcement of such norms arguably are nonjusticiable. See Winter, Poverty, Economic Equality, and the Equal Protection Clause, 1972 SuP. CT. REv. 41 (courts institutionally ill-equipped to enforce constitutional welfare rights).

28. See Michelman, supra note 22, at 1247 ("It is of course true of . . constitutional limitations . . that courts cannot by themselves enforce to the limits of social desirability the values or principles embodied in the limitations."); $c f$. L. TRIBE, supra note 25, at 307 ("Rights . . . reflect values; they are not the values themselves."). Of course, the doctrinal balance struck between competing substantive and structural norms is not static: continual re-evaluation of the norms' content and relative import engenders a dialectic concerning their appropriate mediation. Compare the vastly different visions of judicial enforcement of substantive norms underlying Brown v. Board of Educ., 347 U.S. 483 (1954) and Washington v. Davis, 426 U.S. 229 (1976).

29. That a constitutional norm can influence the design of a remedy without itself specifying the content of the right infringed may seem counterintuitive, as it controverts the traditional maxim that a remedy is entailed by the right it seeks to secure and, conversely, that the remedy provided itself defines the scope of the underlying right. See, e.g., Milliken v. Bradley, 418 U.S. 717, 744 (1974) ("the scope of the remedy is determined by the nature and extent of the constitutional violation").

But in fact it is the traditional maxim that is misleading. A legal right always entails the scope of its appropriate corresponding remedy, but frequently alternative particular remedial decrees can be designed which conform to that scope. In the context under discussion, both extension and nullification (as well as an infinite number of alternative decrees establishing parity) adequately secure the right to equal treatment, but neither is entailed by or defines that right.

A court therefore must look beyond the doctrinal right for guidance when choosing between particular remedies, and it is perfectly plausible for a constitutional norm to provide such guidance. This claim is perhaps most intuitive where the norm directing the remedial choice is unrelated to the norm motivating the doctrinal right. For example, some scholars suggest that courts should decide whether to apply retrospectively a new remedial rule designed to vindicate rights of accused persons, e.g., the exclusionary rule, by appealing to constitutional values of due process and fairness. See, e.g., L. TRIBE, supra note 25 , at 26 . Indeed, courts' occasional appeal to due process values when choosing a particular remedy for a criminal law's violation of equal treatment, see supra note 14, exemplifies this claim in the very remedial context at issue.

The logic of this claim remains even where the same norm motivates both the doctrinal right and the particular remedial choice, once it is acknowledged that doctrinal rights often fail to capture the outer contours of their underlying substantive norms. Unenforced margins or inchoate norms can be viewed simply as separate and discrete constitutional values which are not constitutive of the doctrinal right, yet which can influence the choice of a particular doctrinally-adequate remedy. The exclusively remedial role of inchoate norms is thus perfectly consistent conceptually with the traditional understanding of the right-remedy relationship.

In addition, this remedial role is consistent with the courts' institutional role in constitutional adjudication: the structural concerns motivating the exclusion of inchoate norms from doctrinal expression 
tions explore applications of equal treatment doctrines in First Amendment and sexual equality jurisprudence and identify two inchoate norms that dictate a constitutional preference for one remedy over the other.

\section{A. Inchoate Norms in First Amendment Jurisprudence}

The Supreme Court has often invoked an equal treatment doctrine to enforce the First Amendment, prohibiting government from regulating speech in a manner that discriminates against particular speakers or ideas. ${ }^{30}$ In Police Department of Chicago v. Mosley, ${ }^{31}$ for example, the Court held that an ordinance forbidding all picketing near schools except for peaceable picketing concerning labor disputes violated the equal protection clause. ${ }^{32}$ The Court proclaimed an "equality of status in the field of ideas," holding that "government must afford all points of view an equal opportunity to be heard."ss Because the Court did not hold that a narrowly tailored but content-neutral picketing ban would impermissibly burden speech, ${ }^{34}$ the statutory infirmity theoretically could have been cured either by extending the burden to prohibit all (at least disruptive) picketing near schools or by nullifying the entire regulation. ${ }^{35}$ Under the current remedial model, the proper choice is that which replicates what the enacting legislature would have preferred..$^{38}$

However, this rule of decision fails to acknowledge the constitutional

are inapposite at the remedial stage. See infra text surrounding note 73.

30. See generally Karst, Equality as a Central Principle in the First Amendment, 43 U. CHI. L. REV. 20 (1975).

31. 408 U.S. 92 (1972).

32. While resting its decision on the equal protection clause, the Court seemed to recognize an equal treatment principle inhering in the First Amendment itself. See id. at 95 ("the equal protection claim in this case is closely intertwined with First Amendment interests"); Karst, stpra note 30, at 26-29.

33. 408 U.S. at 96 (citation omitted).

34. The Court sanctioned the constitutionality of "narrowly drawn statutes focusing on the abuses and dealing evenhandedly with picketing regardless of subject matter." Id. at 102 (citation omitted). See Carey v. Brown, 447 U.S. 455,459 n.2 (1980) ("Because we find the present [analogous] statute defective on equal protection principles, we likewise do not consider whether a statute barring all residential picketing regardless of its subject matter would violate the First and Fourteenth Amendments.").

35. See Comment, Equal But Inadequate Protection: A Look at Mosley and Grayned, 8 HARv. C.R.-C.L. L. REv. 469, 475-77 (1973). The Court in fact affirmed the lower court's decision to nullify the ban.

36. Courts similarly have invalidated the discriminatory provision of speech-related benefits such as campaign subsidies, reduced postal rates, and tax exemptions for lobbying purposes as inconsistent with this equal treatment doctrine. If Congress enacted a campaign financing scheme which provided substantial federal subsidies to the Democratic Party only, the law surely would be invalidated on equal protection grounds because it excludes the Republican Party and thus discriminates between similarly situated "major" parties. Because political parties have no substantive right to the provision of campaign subsidies, of. Regan v. Taxation With Representation, 461 U.S. 540, 546 (1983) (rejecting "notion that First Amendment rights are somehow not fully realized unless they are subsidized by the State"), the reviewing court would choose between extension and nullification according to the presumed legislative will. 
preference between the two choices suggested by an inchoate First Amendment norm underlying the doctrinal mandate of equal treatment. The Supreme Court has declared that "the central purpose of the Speech and Press Clauses was to assure a society in which 'uninhibited, robust, and wide-open' public debate concerning matters of public interest would thrive." ${ }^{37}$ This vision is motivated by the special structural role that the First Amendment plays in the social and political organization of our polity: a robust exchange of ideas helps promote the collective selfgovernment integral to our notions of democracy ${ }^{38}$ and enhances the broader "truthseeking" function of the marketplace of ideas. ${ }^{39}$

Direct judicial enforcement of the full scope of this normative vision of a robust public debate would frustrate separation of powers principles: if all laws even incidentally dampening the exchange of ideas were invalidated, government's ability to promote important societal interests might be crippled. Recognizing this, the Supreme Court has developed a First Amendment doctrine which does not always completely realize the underlying public debate norm. However, by embracing content-neutrality as a mediating principle designed to actualize the concept of an optimal public debate and by imposing a narrower doctrinal equal treatment requirement on government actions, ${ }^{40}$ courts can still protect against "government control over the search for political truth"41 while allowing legislatures more freedom to promote the public interest. ${ }^{42}$ Yet, because it does not fully

37. Buckley v. Valeo, 424 U.S. 1, 93 n.127 (1976) (quoting New York Times Co. v. Sullivan, 376 U.S. 254, 270 (1964)). See also FCC v. League of Women Voters, 468 U.S. 364, 380 (1984) (invoking "public's First Amendment interest in receiving a balanced presentation of views on diverse matters of public concern"); Associated Press v. United States, 326 U.S. 1, 20 (1945) (First Amendment "rests on the assumption that the widest possible dissemination of information from diverse and antagonistic sources is essential to the welfare of the public").

38. See, e.g., Richmond Newspapers, Inc. v. Virginia, 448 U.S. 555, 587 (1980) (Brennan, J., concurring) ("the First Amendment embodies more than a commitment to free expression and communicative interchange for their own sakes; it has a structural role to play in securing and fostering our republican system of seif-government"); A. Meiklejohin, Free SPEech and iTs Relation to SElF-Government (1948); Emerson, Toward a General Theory of the First Amendment, 72 Yale L.J. 877, 882-84 (1963).

39. See, e.g., Abrams v. United States, 250 U.S. 616, 630 (1919) (Holmes, J., dissenting); Emerson, supra note 38 , at $881-82$.

40. For other doctrinal manifestations of the underlying norm of a robust debate, see, e.g., Richmond Newspapers, Inc. v. Virginia, 448 U.S. 555 (1980) (access of press to criminal trials); New York Times Co. v. Sullivan, 376 U.S. 254 (1964) (defamation); Perry, Freedom of Expression: An Essay on Theory and Doctrine, 78 Nw. U.L. Rev. 1137, 1194-200 (1984) (right to know).

41. Consolidated Edison Co. v. Public Service Comm'n, 447 U.S. 530, 538 (1980).

42. Courts arguably are institutionally more competent to invoke an equal treatment doctrine than other plausible doctrinal constructs. Before concluding that a law dampening speech is unconstitutional, a court must assess the strength of the legislature's interests in order to balance them against the First Amendment infringement. When a law treats different speakers or ideas differently, the court's task of assessing the importance of the interests at stake is easier: the legislature's willingness to tolerate some speech isolates more clearly its real interests in regulating other speech. See, e.g., Metromedia, Inc. v. City of San Diego, 453 U.S. 490, 520 (1981) ("[E]xceptions to the general prohibition are of great significance in assessing the strength of the city's interest in prohibiting bill- 
secure an optimal public debate, courts' enforcement of an equal treatment doctrine generates a norm-doctrine gap. ${ }^{43}$

The public debate norm does however express a constitutional preference for a particular remedy once a court identifies an equal treatment violation. For example, although in Mosley the equal protection clause was indifferent between allowing everyone or no one to picket peaceably near schools, the public debate norm was not: nullifying the regulation entirely would better promote a robust exchange of ideas. ${ }^{44}$ The Constitution thus is not always indifferent between extension and nullification; rather, an inchoate First Amendment norm often prefers the remedial choice of "more speech, not enforced silence."

\section{B. Inchoate Norms In Sexual Equality Jurisprudence}

The ongoing judicial and academic dispute over the proper doctrinal manifestation of the Fourteenth Amendment's concern with sexual equality reflects a similar inability of doctrine to capture fully its underlying norm. By focusing on the interplay between a federal statutory equal treatment requirement and state laws requiring employers to provide female employees with maternity leave, this Section illustrates the remedial implications of an inchoate constitutional concern about the disadvantaging and disempowerment of women.

Pregnancy is an employment "disability" unique to women. To require the market to accommodate childbearing, several states have passed laws prohibiting private employers from dismissing women because of their

boards."); Mosley, 408 U.S. at 100-02. Used as a doctrine of first resort, equal treatment appeases concerns about judicial competence.

43. The conceptual and institutional impediments to judicial enforcement of the full vision of a robust public debate arise even more forcefully when one contemplates the prospect of judicial enforcement of affirmative legislative action to improve the debate, e.g., through market intervention, private rights of access, or subsidies. First, courts would encounter grave conceptual difficulties when attempting to determine in principled fashion the exact contours of the most "robust" debate. See Baker, Scope of the First Amendment Freedom of Speech, 25 UCLA L. Rev. 964, 987 (1978). Second, judicial enforcement of such affirmative government actions contravenes the state action doctrine and threatens judicial intrusion on the spending power. See supra notes 25-26 and accompanying text. The Court has therefore similarly embraced a neutrality requirement (albeit a less stringent one, see Emerson, The Affirmative Side of the First Amendment, 15 GA. L. REv. 795, 802-03 (1981)) pertaining to government efforts to promote speech.

Of course, under certain circumstances courts can effectively require legislatures affirmatively to promote speech while still themselves acting only negatively. See, e.g., Schneider v. State, 308 U.S. 147 (1939) (invalidating pamphleteering prohibition designed to avoid cleanup costs, thereby "forcing" state to subsidize speech by providing sanitation services); see also L. TRIBE, supra note 25 , at 8. For persuasive arguments that courts ought to enforce an affirmative legislative duty to promote a richer public debate in contexts where institutional constraints are inapposite, see Emerson, supra, at 805-12 (provision of public facilities as speech forums and development of "right to know"); Perry, supra note 40, at 1194-210 (same).

44. Analogously, extension of government benefits provided to enhance participation in the debate, e.g. campaign subsidies, would better service the underlying norm.

45. Whitney v. California, 274 U.S. 357, 377 (1927) (Brandeis, J., concurring). 
pregnancy.$^{48}$ California, for example, requires private employers to allow female employees " $[t]$ o take a leave on account of pregnancy for . . . that period [not exceeding four months] during which the female employee is disabled on account of pregnancy, childbirth, or related medical conditions." 47 Employers must extend such leave regardless of whether they extend similar leave to employees who suffer other disabilities.

These state laws have been challenged as being preempted under the Supremacy Clause ${ }^{48}$ by the federal Pregnancy Discrimination Act of 1978 ("PDA"). 9 The PDA commands that "women affected by pregnancy ... shall be treated the same . . . as other persons not so affected but similar in their ability or inability to work." maternity leave laws argue that this language, construed in light of the Act's legislative history, compels covered private employers to accord pregnancy the same treatment afforded to analogous disabling illnesses and injuries experienced by non-pregnant workers. ${ }^{51}$ If the Supreme Court embraces this interpretation, ${ }^{52}$ the state laws' directive that pregnant women be afforded specific maternity leave rights no matter how comparable disabilities are treated will conflict with the federal statute's command that all workplace disabilities be treated the same. ${ }^{.3}$ Since the

46. See Cal. Gov't Code $\$ 12945$ (West 1980); Conn. Gen. Stat. Ann. § 46a-60(a)(7) (West Supp. 1986); Mass. Gen. Laws ANN. ch. 149 § 105D (West 1982); MonT. Code ANN. § 49-2-310 (1985).

47. Cal. Gov't Code $\S 12945$ (b)(2) (West 1980).

48. U.S. Const, art. VI, cl. 2.

49. The Pregnancy Discrimination Act of 1978,42 U.S.C. $\S 2000 \mathrm{e}(\mathrm{k})(1981)$, amends the definitional provisions of Title VII of the Civil Rights Act of 1964, 42 U.S.C. $\$ 2000 \mathrm{c}-2000 \mathrm{e}(17)$ (1981), which proscribes sex discrimination in private employment.

50. 42 U.S.C. § $2000 e(k)$ (1981).

51. Whether the PDA actually imposes such an equal treatment requirement is not yet settled. Several courts have construed the PDA to require equal treatment of pregnant and non-pregnant employees. See, e.g., Barone v. Hackett, 602 F. Supp. 481, 483 (D.R.I. 1984); Connors v. Univ. of Tenn. Press, 558 F. Supp. 38, 40-41 (E.D. Tenn. 1982); Marafino v. St. Louis County Cir. Ct., 537 F. Supp. 206, 212 (E.D. Mo. 1982), affd, 707 F.2d 1005 (8th Cir. 1983).

However, two courts have recently upheld the California and Montana statutes against preemption claims, interpreting the PDA not to impose a rigid equal treatment requirement. See Cal. Fed. Sav. \& Loan Ass'n v. Guerra, 758 F.2d 390 (9th Cir. 1985), cert. granted, 106 S. Ct. 783 (1986); MillerWohl Co. v. Comm'r of Labor \& Indus., 692 P.2d 1243 (Mont. 1984). For scholarly support of this interpretation, see Krieger \& Cooney, The Miller-Wohl Controversy: Equal Treatment, Positive Action and the Meaning of Women's Equality, 13 GoLDEN GATE U.L. REV. 513 (1983); Note, Employment Equality Under the Pregnangy Discrimination Act of 1978, 94 YALE L.J. 929 (1985).

I do not analyze here either the validity of this equal treatment statutory interpretation or the merits of the preemption challenge; rather, to engage the resultant remedial question, I simply assume judicial application of a statutory equal treatment requirement and a ruling of preemption.

52. The Supreme Court recently issued a writ of certiorari to review the preemption question. See Cal. Fed. Sav. \& Loan Ass'n v. Guerra, 106 S. Ct. 783 (1986).

53. The federal and state laws actually can coexist operationally. The PDA assertedly requires equal treatment; the state laws simply establish the substantive benefits to which pregnant women are entitled, giving content to the federally imposed equality relation. However, the state laws' authorization of unequal treatment is incompatible with the federal objective under the interpretation assumed here, as the laws become compatible only after employers are required to extend analogous benefits to other disabled workers. Because operational compatibility presumes extension, it does not obviate the 
Supremacy Clause dictates that a federal law supersedes any state law conflicting or interfering with the former's objectives, ${ }^{54}$ the state laws treating women and men differently would be preempted.

This conflict could be resolved by either extension or nullification of the state laws; the Supreme Court would have to decide whether to require employers to provide non-pregnant workers with leave for all analogous disabilities or to invalidate the state requirement entirely. ${ }^{\mathrm{ss}}$ Under the current remedial model the Court would base its decision on the presumed intent of the relevant state legislature. ${ }^{56}$

This inquiry is misguided. Contrary to the current model's premise, the Constitution is not indifferent to the remedial choice. The Supreme Court has constructed and invoked equal protection doctrine to invalidate laws treating women and men differently based on sex-role stereotypes. Underlying this doctrine is a constitutional concern about the disempowerment of women, a concern that favors extension of these state maternity leave laws.

The Supreme Court has held repeatedly that sex-based classifications importing stereotypes about proper sex-roles contravene the Fourteenth Amendment's conception of equality. ${ }^{57}$ This is not because stereotyping is

pre-judgment tension between the two statutes' commands.

54. See, e.g., Silkwood v. Kerr-McGee Corp., 464 U.S. 238, 248 (1984) (state law is preempted if it "stands as an obstacle to the accomplishment of the full purposes and objectives of Congress").

55. In this context a court's decision about the preferred remedial alternative actually dictates its decision on the merits. If the Supreme Court chooses to nullify the maternity leave requirement, it will simply declare the state law to be preempted and hence void. However, if the Court prefers to "extend" the provision of leave to cover other disabilities, it can but need not declare the state law preempted and then extend it as a remedy. Rather, it can uphold the state statute and explicitly articulate the coincident equal treatment requirement of the federal law, in effect "extending" the state law's coverage by imposing a concurrent federal duty on employers to broaden their benefit programs. See, e.g., Potlatch Forests, Inc. v. Hays, 318 F. Supp. 1368 (E.D. Ark. 1970) (employer ordered to comply with both Title VII and state law requiring overtime wages for women by extending benefits to men); Brown, Emerson, Falk \& Freedman, supra note 14, at 926 n.107.

56. See Kanowitz, supra note 6, at 1415; Note, Employment Practices and Sex Discrimination: Judicial Extension of Beneficial Female Protective Labor Laws, 59 CoRNell L. Rev. 133 (1973). Of course, if Congress is found to have gone beyond a mere equal treatment requirement and evinced a clear remedial preference concerning laws and practices declared inconsistent with such a mandate, the federal intent would supersede that of the state. By definition both the state law and the state's preferred remedial response would be preempted by the federal statutory scheme.

57. See, e.g., Mississippi Univ. for Women v. Hogan, 458 U.S. 718 (1982) (invalidating femalesonly admissions process for nursing school); Califano v. Westcott, 443 U.S. 76, 87-88 (1979) (rejecting statute's reliance on stereotyped assumption that male spouse is primary wage-earner); Stanton v. Stanton, 421 U.S. 7, 14-15 (1975) (rejecting statute's reliance on assumption that "female [is] destined solely for the home and the rearing of the family, and only the male for the marketplace and the world of ideas").

The Supreme Court has acknowledged the subtlety with which ideas and attitudes about the proper roles of the sexes invidiously influence legislative deliberations, describing the adoption of sexually discriminatory laws as the "accidental byproduct of a traditional way of thinking about females," Galifano v. Goldfarb, 430 U.S. 199, 223 (1977) (Stevens, J., concurring), and the "product of habit, rather than analysis or reflection," Lehr v. Robertson, 463 U.S. 248, 266 n.24 (1983). 
per se unconstitutional, ${ }^{\mathrm{68}}$ but because sex-role stereotypes reinforce an entrenched social dynamic of women's oppression and subordination. ${ }^{59}$ All laws overlay a preexisting social reality of sexual inequality, as women are systematically relegated to subordinate and devalued positions in our political, economic, and social institutions. This socially constructed hierarchy generates stereotypes concerning the "proper" roles of women in public and private life, which in turn reinforce and legitimize the hierarchy. A sex-based legal classification which imports and hence perpetuates these social stereotypes thereby contributes to the institutionalization of the economic and social subordination of women. Hence, behind the Supreme Court's antipathy towards sexual stereotypes lies a concern about the role that stereotyping classifications play in reinforcing the ongoing cycle of women's subordination: "the primary constitutional infirmity in such classifications is not that they are inaccurate, but that they are. selffulfilling."

This underlying concern has not been completely captured by legal doctrine. The very complexity of this social dynamic and the entrenched nature of existing stereotypes and inequality makes the creation of some norm-doctrine gap unavoidable, ${ }^{61}$ and the Supreme Court's fear of exces-

58. See, e.g., Williamson v. Lee Optical, 348 U.S. 483 (1955) (upholding law premised upon stereotyped differences between opticians, optometrists, and opthalmologists); $c f$. J. Ely, DeMOCRACY AND DisTrust 156 (1980) ("stereotypes ... . are the inevitable stuff of legislation").

59. See Sherry, Selective Judicial Activism in the Equal Protection Context: Democracy, Distrust, and Deconstruction, 73 GEo. L.J. 89, 111 (1984) (the "distinction between a statute based on inaccurate generalizations about the differences between opticians and optometrists . . . and a statute based on inaccurate generalizations about the differences between men and women . . . must be that only in the latter case is one class consistently denigrated in popularly accepted stereotypes").

60. Law, Rethinking Sex and the Constitution, 132 U. PA. L. REv. 955, 995 (1984). The Court has expressly articulated this concern only rarely. But see Parham v. Hughes, 441 U.S. 347,354 (1979) (a "State is not free to make overbroad generalizations based on sex . . . which demean the ability or social status of the affected class"). Yet, not only does this concern best explain the Court's condemnation of sex-role as opposed to other stereotypes, but it also historically motivated in lange part the Court's decision to apply heightened scrutiny to sex-based classifications. See, e.g., Frontiero v. Richardson, 411 U.S. 677, 684-86 (1973) (plurality opinion) (strict scrutiny justified because of, inter alia, past and present pervasive discrimination against women due in part to role-typing); Sherry, supra note 59, at 108-14 (traditional criteria for suspectness reflect underlying concern with class status).

In addition, this concern for women's oppression can be seen at work in many of the Court's opinions. For example, in Mississippi Univ. for Women v. Hogan, 458 U.S. 718 (1982), the Court found that the Nursing School's purportedly "benign" policy of females-only admission incorporated stereotyped attitudes about the proper role of women in the medical profession: sex-segregation "tends to perpetuate the stereotyped view of nursing as an exclusively woman's job." Id. at 729. The Court further noted that the admissions policy "Ien[t] credibility to the old view that women, not men, should become nurses, and makes the assumption that nursing is a field for women a self-fulfilling prophecy." Id. at 730 . Finally, the Court acknowledged that this stereotype leads to the material disadvantaging of women, noting that sex-segregation has resulted in the depression of nurses' wages such that the "admissions policy actually penalizes the very class the State purports to benefit." Id. at 729-30 n.15.

61. The mutual reinforcement of sex-role stereotyping and the subordination of women is so powerful that doctrinal efforts to address one side of the dynamic inevitably seem to undermine efforts to address the other. An equal treatment doctrine successfully terminates the cycle by proscribing new 
sive interference with legislative allocations seems independently to have convinced it to maintain a gap out of respect for competing institutional values. ${ }^{62}$ Rather than adopting a more ambitious doctrinal stance, the Supreme Court has embraced an equal treatment doctrine that presumptively proscribes stereotyping sex-based classifications. However, the constitutional concern about women's subordination still expresses a preference for either extension or nullification when a court invalidates an underinclusive sex-based law, as one remedy often will more fully empower women. ${ }^{.3}$

In the context of state maternity leave statutes, this concern suggests a constitutional preference for extension rather than nullification of these laws if they are held to conflict with a federal equal treatment requirement. Because of pregnancy's sex-specificity, women can be relegated to inferior economic and social status by an equal provision of zero disability leave benefits. Any policy failing to cover the period during which a woman must stop working to bear a child is tantamount to a policy of firing

laws importing pernicious stereotypes. See, e.g., Olsen, The Family and the Market: A Study of Ideology and Legal Reform, 96 HARv. L. REv. 1497, 1551-52 (1983). The same doctrine, however, also proscribes compensatory laws such as state mandated maternity leave statutes designed to advantage and empower women.

An alternative doctrinal construction would have the judiciary invalidate every law which "integrally contributes to the maintenance of an underclass or a deprived position because of gender status." C. Mackinnon, Sexual Harassment of Working Women 117 (1979). See Law, supra note 60 (applying MacKinnon's "inequality approach" only to laws concerning reproductive biology). However, this doctrine's validation of sex-based laws compensating for existing inequalities potentially would initiate the cycle of legal perpetuation of stereotyping all over again: "recognition of the reality of oppression, particularly in the case of women, can perpetuate derogatory stereotypes." Id. at 965 n.29. See Taub, Sexual Harassment of Working Women: A Case of Sex Discrimination (Book Review), 80 Colum. L. REv. 1686, 1690-93 (1980). In addition, history suggests that any doctrine validating differential treatment on the basis of sex in a legal system traditionally unresponsive to women's concerns inevitably will be used to further disadvantage women. See Williams, The Equality Crisis: Some Reflections On Culture, Courts, and Feminism, 7 WoMEN's RTS. L. REP. 175, 196 (1982).

Hence, neither an equal treatment doctrine nor an "inequality approach" successfully captures the full scope of the root problem of sexual inequality. See C. MAcKinNon, supra, at 144 (declaring "the persistent dilemma of discrimination law" to be "how to lift some of the burdens of inequality without intensifying them in the same act").

62. The Court's adoption of a motive-based inquiry under the Fourteenth Amendment and its focus on explicit sex-based classifications can perhaps best be explained by a desire to curb the considerable extent of judicial invalidation of legislation arguably occasioned by an effects test such as Professor MacKinnon's. See Note, Making the Violation Fit the Remedy: The Intent Standard and Equal Protection Law, 92 YALE L.J. 328 (1982).

63. See, e.g., Olsen, supra note 61, at 1554 (neutral provision of benefits can empower women). Invoking this preference as a remedial guide will help eliminate the present effects of past legal discrimination, a remedial goal reflected elsewhere in equal protection jurisprudence. See generally Gewirtz, Choice in the Transition: School Desegregation and the Corrective Ideal, 86 Colum. L. REv. 728 (1986) (discussing and applying "corrective" remedial model to school desegregation). The present social and economic oppression and disempowerment of women was generated at least in part by previous laws creating and maintaining a "separate spheres" ideology, see, e.g., Brown, Emerson, Falk \& Freedman, supra note 14, at 898 ; Olsen, supra note 61 , at $1547 \mathrm{n} .184$, and compensating for these disadvantages by choosing the preferred parity remedy helps to erase these remnants of past discrimination. 
all women who become pregnant. By nullifying these state laws as a remedial starting point, the Court would enable employers to continue defining pregnancy as incompatible with normal employment, severely impairing women's ability to compete effectively with men in the marketplace. ${ }^{64}$ In contrast, extending the state maternity leave laws to secure leave to non-pregnant workers for their illnesses and injuries similarly disabling them from work would both protect women against termination because of pregnancy and avoid the stereotyping danger inherent in sex-based classifications. Thus, extension both remedies the specific doctrinal violation and better realizes the underlying equality norm.

This inchoate norm similarly asserts a preference for specific remedial choices after the invalidation of other sex-based laws. Where underinclusive laws purport to empower women by compensating for background inequalities, extending the benefits to both sexes would ensure that the goal of empowerment is still furthered. ${ }^{65}$ In contrast, extending coverage of a sex-based law working to women's disadvantage might perpetuate

64. Given that greater than 80 percent of females in the labor force are likely to become pregnant at least once during their working lives, see Krieger \& Cooney, supra note 51, at 519, the lack of maternity leave has a tremendous impact on working women as a class. Women inevitably become viewed as, and often become, short-term marginal workers. This disrupts their ability to move upwards within occupational hierarchies and pushes them into lower status, sex-segregated occupations where high turnover rates are more compatible with productive activity, thus depressing their wages. In enacting the PDA, Congress recognized that the interpenetrative effects of pregnancy discrimination and job segregation exacerbate the female-male wage gap. See Scales, Towards a Feminist Jurisprudence, 56 IND. L.J. 375, 402-03 (1981).

65. For example, the Massachusetts maternity leave law also requires employers to provide childrearing leave for female employees who adopt young children. MASS. GEN. LAwS ANN. 149 § 105D (West Supp. 1986). If a court finds that this non-biologically based classification violates the Fourteenth Amendment by perpetuating sex-role stereotypes, see supra note 57, the court should extend the provision's coverage to fathers as well. Since women are still usually the primary childrearers within a family, a no-leave provision will disproportionately disadvantage them in the workplace with respect to men as a class, just as does the lack of a maternity leave provision.

In Orr v. Orr, 440 U.S. 268 (1979), the Supreme Court invalidated a law allowing women but not men to be awarded alimony upon divorce. Such an award was intended to compensate women for their presumed lack of opportunity to stockpile independent wealth during marriage. Either the Supreme Court or the state supreme court upon remand could have invoked the inchoate constitutional concern for redressing past stereotyping and disadvantaging to extend the statute's coverage to allow both sexes to be awarded alimony-a no-alimony policy, given existing differences in the earning power of most men and women, would have a negative disparate impact on women and hence maintain their depressed levels of financial independence.

In Michael M. v. Superior Court, 450 U.S. 464 (1981), the Supreme Court upheld a statutory rape law punishing males but not females participating in sexual intercourse where the female was a minor. The sex-based statute benefits women by taking account of unequal power relationships in the sexual realm and empowering women to challenge and resist male sexual coercion, but it also reinforces the sexual stereotype of men as sexual aggressors and women as passive victims. See Olsen, Statutory Rape: A Feminist Critique of Rights Analysis, 63 TEx. L. REV. 387, 412 (1984). If the state law had been invalidated by the Court, extension of the law's coverage to punish members of either sex having intercourse with minors would have established parity such that women would still have been empowered by the law. 
that disadvantage because of a disparate impact on women. In such circumstances the equality norm argues for nullification. ${ }^{68}$

\section{Judicial Actualization of Inchoate Norms Through a NORM-BASEd REMEDIAL MODEL}

Deference to legislative preferences is appealing given a desire to limit judicial policymaking, and given the premise that once courts fully protect doctrinal rights no further substantive constitutional values inform the remedial decision. But the preceding analysis exposes this premise as false: courts often fail to capture the full conceptual scope of substantive norms. While the inchoate norms may prefer a specific allocation of benefits or burdens, mandating this allocation is beyond the institutional province of courts, and hence legislatures retain the authority to determine the ultimate equal distribution of benefits and burdens free from judicial restraint. ${ }^{67}$ Although courts cannot enjoin their permanent protection, however, courts facing the extension/nullification decision can appeal to these inchoate norms for principled guidance. And by so setting the remedial starting point, courts would structure a judicial-legislative colloquy concerning the significance of these norms, thereby promoting their realization while simultaneously respecting the legislature's authority to help shape remedies for constitutional violations. ${ }^{68}$ Recognition of the underenforced margins of substantive norms thus warrants reformulation of the remedial enterprise: rather than choose the remedy most consistent with

66. For example, in Phillips v. Martin Marietta Corp., 400 U.S. 542 (1971), the Supreme Court invalidated under Title VII of the Civil Rights Act an cmployment policy excluding mothers but not fathers of preschool children from applying for a particular job based on the assumption that women's primary childrearing responsibilities would interfere with their employment. Had the Court imposed a parity remedy excluding primary childrearers of either sex, the burden of exclusion would still have fallen disproportionately on women and the stereotype that mothering and employment are incompatible would have been perpetuated. Abolishing the exclusionary policy altogether would be the constitutionally preferred remedy.

67. Of course, legislators themselves still have a constitutional obligation to act consistently with the full contours of constitutional norms. See Brest, The Conscientious Legislator's Guide to Constitutional Interpretation, 27 STAN. L. REv. 585, 587-89 (1975) (legislative duty to interpret and enforce norms without regard to institutional constraints on courts); Sager, supra note 20, at 1264 (legislative duty to "obey the full scope of constitutional norms which are underenforced by the federal courts"). Hence these norms still should provide internal constraints on legislative action, consistent with Justice Holmes' admonition that "legislatures are ultimate guardians of the liberties and welfare of the people in quite as great a degree as the courts." Missouri, Kan. \& Tex. Ry. Co. v. May, 194 U.S. 267, 270 (1904).

68. See A. Bickel, The Least Dangerous Branch 240 (1962) ("The Court does not work in isolation to divine the answer that is right. It has the means to elicit partial answers and reactions from the other institutions, and to try tentative answers itself."); $c f$. Cover \& Aleinikoff, Dialectical Federalism: Habeas Corpus and the Court, 86 YALE L.J. 1035 (1977) (federal and state court dialectic best translates constitutional values into secured rights for criminally accused). 
policies underlying the statutory scheme, courts should select the remedy that best promotes values embedded in the constitutional text. ${ }^{68}$

Such a norm-based remedial model simply requires courts to engage in the same kind of interpretive inquiry as before, but with respect to a superior form of law. Where a specific statutory provision conflicts with a specific constitutional mandate, instead of looking beyond the statutory provision to surrounding legislative purposes, courts should look beyond the doctrinal mandate to underlying and surrounding constitutional values. This new direction better comports with the judiciary's institutional obligation in constitutional adjudication: "to give concrete meaning and application to our constitutional values." doctrinal right, thereby justifying corrective judicial intervention, courts must vindicate constitutional values both by articulating the rights at stake and by aggressively fashioning remedies to protect the threatened constitutional norms. And, since rights and remedies constitute "two phases of a single social process [of giving] meaning to our public values,"71 courts can fully discharge their institutional obligation only by choosing that remedy best serving the body of norms underlying rights. ${ }^{72}$

This remedial obligation is consistent with respect for institutional values, as the conceptual and structural constraints which circumscribe the occasions for the initial judicial intervention no longer fetter a court when it is called upon to remedy an equal treatment violation. Judicial restraint

69. Courts have already drawn remedial guidance from due process values when deciding whether to extend or nullify discriminatory criminal statutes, see supra note 14 . Express adoption of the normbased remedial model would simply encourage an expanded search for implicated constitutional norms and greater candor regarding their invocation. In situations where no inchoate norms express a remedial preference, courts should continue to defer to the policy preferences of the legislature as best can be discerned.

Whether a federal constitutional challenge to an underinclusive statute (including a preemption challenge) is litigated in a state or federal forum, the reviewing court ought first to look to the same federal constitution for inchoate norms guiding the remedial decision. Most state constitutions embrace a somewhat broader set of norms than their federal counterpart; when this difference is relevant, a state or federal court holding a state statute underinclusive should turn to the state constitution for guidance where the federal constitution provides none. When a state statute is challenged on state constitutional grounds only, the reviewing state court should simply look to the state constitution.

70. Fiss, The Supreme Court, 1978 Term-Foreword: The Forms of Justice, 93 Harv. L. REv. 1, 9 (1979). Of course, courts do and should perform other adjudicatory tasks, such as statutory interpretation, in non-constitutional contexts. Yet when resolving conflicts between constitutional and statutory law, courts must recognize the Constitution's status as a superior form of law: interpretation and actualization of constitutional values constitute the judiciary's preeminent institutional calling.

71. Fiss, supra note 70 , at 52 .

72. See Dellinger, Of Rights and Remedies: The Constitution as a Sword, 85 HARv. L. REv. 1532,1534 (1972) (defending "judicial prerogative to fashion remedies that give flesh to the word and fulfillment to the promise [constitutional] norms embody").

For an analogous vision of the remedial enterprise occasioned by structural reform litigation, see Fiss, supra note 70, at 47-48 (after finding that government institution (such as school or prison) operates so as to infringe upon constitutional rights, court should restructure the institution to terminate the doctrinal violation and remove any additional threats posed to constitutional values, including values other than the one occasioning intervention). 
through underenforcement at the rights declaration stage fully satisfies the general desire to vest a politically accountable body with the ultimate responsibility for most allocative decisions. Judicial extension of benefits does not unduly intrude upon the legislative power of the purse. In terms of process, extension as a remedy (as opposed to a declaration of affirmative rights) preserves the legislature's power subsequently to terminate a costly benefits scheme. In terms of budgetary effect, this objection is not compelling because courts often have implemented costly starting points under the current remedial model. ${ }^{73}$ Finally, the concern that courts are not competent to determine the amount of a benefit required to satisfy a constitutional norm is also inapposite in this remedial context, as a court need only equalize benefits at the level prescribed for those recipients originally included by the enacting legislature.

Hence, given the presence of an inchoate substantive norm and the absence of structural values obliging judicial passivity, ${ }^{\mathbf{7 4}}$ the current model's assumption that courts conclude their "essentially judicial" role simply by mandating equal treatment through either extension or nullification is false. Though both remedies are formally adequate, one is substantively preferred; courts (at least temporarily) can further actualize constitutional norms by choosing the preferred remedy. ${ }^{75}$

Setting the remedial starting point in this manner maintains respect for the legislature's authority to participate in the remedial decision; the potential for subsequent legislative review "vitiates any objection that the Supreme Court, in fashioning interstitial rules, violates separation of powers principles vis-a-vis Congress." 26 Indeed, employing the norm-based

73. See supra note 4 and accompanying text. Indeed, courts have often imposed extremely costly remedies in other contexts where the legislature could not legitimately avoid them. See Frug, supra note 26 , at 718-32 (discussing federal courts' implementation of costly structural reform litigation remedies).

74. For an intriguing argument that federal courts should promote the realization of inchoate norms by drawing upon the enforcing actions of other governmental actors that do not face similar institutional constraints, see Sager, supra note 20 (federal courts should defer to Congress' norm enforcement through regulation of state action under Section Five of Fourteenth Amendment and to state courts' interpretation of federal rights more broadly than more institutionally-constrained federal courts).

75. For an argument that courts should and occasionally have employed the equal protection clause in conjunction with the remedy of extension to actualize an unarticulated and completely inchoate right to welfare, see Michelman, Welfare Rights in a Constitutional Democracy, 1979 WASH. U. L.Q. 659 .

In rare instances two inchoate norms might call for contrary remedies. For example, it is at least arguable that extending the discriminatory picketing ban invalidated in Mosley to cover all picketing near schools would have promoted First Amendment values by facilitating the schools' educative function. But see text accompanying note 44 . In such situations courts must determine the relative importance of the two norms in the specific context, just as they must when norms conflict at the doctrinal formulation stage.

76. Monaghan, The Supreme Court, 1974 Term-Foreword: Constitutional Common Law, 89 HaRv. L. REv. 1, 34 (1975) (discussing legislature's "power to revise constitutional common law" such as Miranda and exclusionary rules); Miller, supra note 3, at 146 (subsequent legislative review 
model not only will better execute the judiciary's proper remedial function, but it also will enrich the legislature's contribution by enhancing its subsequent deliberative process. When selecting a particular remedy according to this model, a court necessarily will discuss candidly the source and strength of the constitutional preference expressed by relevant inchoate norms. This discussion will inform the ensuing legislative deliberations and generate normative claims for leaving the court's starting point undisturbed; the legislature therefore is more likely to take account of both constitutional values and policy preferences when formulating its ultimate remedial response.

When viewed from a dynamic perspective, therefore, a norm-based remedial model will generate a judicial-legislative dialogue which in effect imposes a "clear statement" requirement on the legislature, a strategy employed frequently by the Supreme Court to protect constitutional values in other contexts. ${ }^{77}$ If the legislature wishes to shirk its duty to interpret and

\footnotetext{
"takes seriously the legislature's primary role as a dispenser of constitutional remedies").

To be sure, legislative inertia inherent in the normal political process, see supra note 6 , causes a court's choice of a starting point to influence somewhat the likely outcome of subsequent legislative review. But this provides no unique argument against the norm-based approach, as the current legislature's deliberations will be weighted in some direction no matter what criteria the court uses to select a starting point.

Furthermore, there is little reason to believe that the norm-based approach would set inertia against the current legislature's desires more often than does the current remedial model, since an enacting legislature's remedial preference is often a poor predictor of the current legislature's. See supra note 9. Hence even if an overriding desire to avoid the countermajoritarian selection of starting points were appropriate, it does not argue persuasively in favor of retaining the current intent-based model. Rather, it encourages adoption of a remedial model according to which courts select the starting point they believe the current legislature would implement as an ending point in the absence of any inertia. Cf. Coleman \& Kraus, Rethinking the Theory of Legal Rights, 95 YALE L.J. 1335, 1336 (1986) (courts promote efficiency in presence of prohibitive transaction costs by initially allocating entitlement to party most likely to emerge with it in hypothetical Coasean market). However, not only are courts ill-equipped to engage in such an inquiry, see G. CALABRESI, supra note 6, at 94, 100, but the overtly political nature of the enterprise-constructing a collective intent without the aid of any of the traditional interpretive guides such as a text-arguably transcends the bounds of propriety for an independent judiciary.
}

77. See, e.g., Wellington, Common Law Rules and Constitutional Double Standards: Some Notes On Adjudication, 83 YAL.E L.J. 221, 264 (1973) (judicial imposition of "clear statement rule" to protect "quasi-constitutional" principles is "both common and legitimate. Its legitimacy stems from the nature of principles and the comparative advantage of courts over legislatures in elucidating principles. Legislative power to disregard [nondoctrinal] principles exists . . . but it must be exercised without doubt."). For example, the venerable canon of statutory construction that statutes admitting of more than one plausible interpretation should be construed to avoid serious doubts as to their constitutionality imposes on legislatures a duty to express clearly their intent to challenge the constitutional line. See, e.g., Ashwander v. Tennessee Valley Authority, 297 U.S. 288, 348 (1936) (Brandeis, J., concurring); United States v. Coombs, 37 U.S. (12 Pet.) 72, 76 (1838).

Indeed, the Supreme Court frequently has employed a clear statement requirement to promote the structural principle that legislatures not delegate critical decisions, especially those implicating constitutional values, to Iess politically accountable agents. See A. Bickel, supra note 68, at 161 ("The more fundamental the issue, the nearer it is to principle, the more important it is that it be decided in the first instance by the legislature."). Nondelegation can be characterized as an inchoate structural norm, one no longer directly enforced through the nondelegation doctrine (last invoked in A.L.A. Schechter Poultry Corp. v. United States, 295 U.S. 495 (1935)), but one indirectly and incompletely 
promote the realization of inchoate constitutional norms, ${ }^{78}$ it can do so only by clearly expressing such an intention through legislation enacted after deliberating with full awareness of the constitutional implications of its choice. Indeed, the Supreme Court has already imposed an analogous requirement on Congress' exercise of its authority to substitute for damage awards an equally effective remedy for claims brought directly under the Constitution. ${ }^{79}$ Far from ignoring the legislature's remedial desire, the norm-based model structures the deliberative environment in which that desire is formed to encourage a reasoned and politically accountable decision; a legislature ultimately choosing not to advance inchoate constitutional values through its allocative decisions will "be made to do so openly and face the consequences before the people." 80 The model thus preserves and enhances both branches' contribution to resolving the remedial dilemma. ${ }^{81}$

enforced through strict statutory construction; courts construe authority-delegating statutes narrowly so as to render the officials' constitutionally questionable actions ultra vires. See, e.g., Lowe v. SEC, 105 S. Ct. 2557, 2572-74 (1985) (SEC not authorized to regulate newsletters disseminating investment advice to general public); Kent v. Dulles, 357 U.S. 116, 129 (1958) (Secretary of State not authorized to withhold passport because of citizen's political activities).

78. See supra note 67.

79. See Sager, The Supreme Court, 1980 Term-Foreword: Constitutional Limitations on Congress' Authority to Regulate the Jurisdiction of the Federal Courts, 95 HARv. L. REv. 17, 88 n.223 (1981) ("Congress may displace judicially created damage remedies only if it explicitly indicates its intent to do so"); Carlson v. Green, 446 U.S. 14, 19 (1980) (upholding damages action under Eighth Amendment where Court found "no explicit congressional declaration" that Congress wanted damages remedy displaced by those authorized by Federal Tort Claims Act); Davis v. Passman, 442 U.S. 228, 246-47 (1979) (upholding damages action for sex discrimination under Fifth Amendment in absence of explicit declaration to contrary in Title VII's remedial provisions).

80. G. CALABRESI, supra note 6, at 17. Subsequent legislative deliberation is especially important in cases where the enacting legislature's impermissible motive necessitated the invalidation. By applying the current remedial model in such cases, courts inevitably will perpetuate inadvertently the legislature's transgression of constitutional values. For example, the same illegitimate attitudes motivating the adoption of stereotyping sex-based classifications (especially where unconsciously held, see supra note 57), surely will be reflected in the policy concerns underlying the statute as enacted and even the legislature's deliberations surrounding its adoption. Basing a remedy on such policy concerns will perpetuate in milder form the very bias constituting the infirmity. In contrast, later courts can more readily screen out such biases underlying a legislature's remedial choice if the legislature must debate the issue openly and explicitly. Cf. Antoine v. Washington, 420 U.S. 194, 199-200 (1975) (applying clear statement rule to statutes and treaties concerning American Indians so that ambiguities always interpreted in Indians' favor; rule justified because enacting Congresses presumed to have been biased and taken advantage of superior bargaining position).

81. One might object that, where a court invokes norms to set starting points concerning issues of extreme political sensitivity, e.g. sexual equality, legislators may be very reluctant to reconsider explicitly the remedial question. In the few instances where such issue-specific inertia will greatly compound the normal level of structural inertia, arguably courts will have both the first and final say, and hence they should take account of both norms and competing policy interests when selecting a remedy.

Even if this objection accurately captures political reality (an empirical question with no obvious answer), the objection does not support retaining the current intent-based model. The enacting legislature's remedial intent is a poor proxy for such a balance: the legislature most likely was either ignorant of or hostile toward the inchoate norms implicated, see supra note 11; infra notes 84-85, and its policy concerns are potentially anachronistic, see supra note 9 . Rather, if valid, the objection argues in favor of courts' considering the two types of concerns themselves and choosing the non-norm-preferred remedy if necessary to advance a compelling governmental interest. But the objection is weak, as its 
In the extremely rare situation where the enacting legislature actually drafted a severability clause pertaining specifically to the particular discriminatory provision found unconstitutional, ${ }^{82}$ one might argue that this pre-invalidation "clear statement" of remedial intent serves the same function as subsequent legislative review and thus deserves judicial respect and deference at the initial remedial stage. ${ }^{83}$ Such a clause's "statement," however, is frequently not as "clear" as it initially might appear. First, the expressed preference may have been tainted by deficiencies in the decisionmaking environment, such as the lack of appreciation of the constitutional values implicated by the remedial choice ${ }^{84}$ or even the presence of illegitimate biases motivating the choice. ${ }^{85}$ Second, rather than reflect an intent about remedies, the clause may reflect a legislative desire to insulate a discriminatory allocation from judicial review. By expressly calling for nullification as a remedy, the legislature eliminates any material incentive for people originally denied benefits to challenge the discrimination. ${ }^{88}$

conclusion begs its own premise: if the policy interest is so compelling as to outweigh the constitutional value, then the claim that legislators will be too paralyzed to vindicate the interest even if they truly so desire becomes extremely implausible. The scenario motivating this objection would rarely, if ever, arise.

Moreover, these few extremely politically sensitive issues most likely are such because they implicate fundamental constitutional values. Where such inertia is generated by public pressure for the statutory realization of norms rather than by structural attributes of the political process, the argument for candid judicial norm-declaration and invocation in the setting of starting points is most compelling. Rather than an impediment to thoughtful subsequent legislative review, this issue-specific inertia simply reflects the concerns that such review should take into account.

82. See supra note 10 and accompanying text. I have not discovered any case except Hechler in which the Supreme Court focused on such a specific severability clause.

83. Even where a court plausibly could discern an unarticulated remedial intent, the legislature's failure to articulate its intent as law constitutes a failure to assert its legislative power to fashion remedies sufficiently to warrant any deference. Cf. supra note 79 (Congress can supplant constitutional damage remedies only by enacting clear law). And, enactment of a general severability clause does not satisfy the clear statement requirement because it cannot fairly be.construed to govern the specific remedial decision at issue. See supra note 10. Moreover, general severability clauses often are enacted out of habit and reflect no actual legislative intent at all. See Stern, supra note 3, at 124 (noting significant trend for "clauses to be attached as a matter of course to all statutes without thought as to what their effect would be").

Where a court defers to a clear statement embodied in a specific severability clause, this statement governs only the court's implementation of prospective relief from the statutory inequality; it cannot dictate the propriety or form of particular retrospective relief. See supra note 8.

84. Lack of legislative deliberation concerning the constitutional ramifications of the remedial choice is especially likely where the law was enacted prior to evolution of the doctrine now mandating invalidation. For example, legislatures placing severability clauses in laws importing sex-based classifications prior to the 1970's probably did not anticipate the precise constitutional issue.

85. Any illegitimate bias undergirding an unlawful classification likely underlies the severability clause as well. See supra note 80 . In the extreme, a legislature may desire so strongly to treat one group poorly that it is willing to treat all people just as poorly if so required. Cf. Palmer v. Thompson, 403 U.S. 217, 224 (1971) (upholding city's decision to close public swimming pools as response to desegregation order despite prejudiced motivation of "ideological opposition to racial integration").

86. See Mathews v. Heckler, 1982 Unempl. Ins. Rep. (CCH) 14,313 at 2408 (N.D. Ala. Aug. 24,1982 ) ("severability clause [urging nullification of benefits] is not an expression of the true congressional [remedial] intent, but instead is an adroit attempt to discourage the bringing of an action"), rev'd, 465 U.S. 728 (1984); Miller, supra note 3, at 145-46. 
Thus, even specific severability clauses enacted prior to judicial invalidation frequently will not provide a clear statement worthy of judicial respect. Courts must carefully scrutinize such clauses and insist on subsequent legislative review where necessary to ensure the integrity of the ultimate remedial decision. ${ }^{\mathbf{8 7}}$

\section{Conclusion}

Incorporating inchoate substantive constitutional norms into a normbased remedial model for underinclusive statutes constitutes only a single step in a larger project of bringing substantive constitutional values more fully to bear on the legal ordering of society: ${ }^{88}$ fully compensating for judicial underenforcement of norms requires development of other institutional responses as well. Explicit recognition and discussion of inchoate

87. It is possible to recharacterize severability clauses as post-invalidation enactments of the prior legislature's intent. The traditional understanding of severability clauses holds that they do not constitute part of a statute's binding legislative directives governing the activity of citizens or officials. Rather, like preambles and enactment clauses, they function as non-binding proclamations concerning the operation of these binding directives; more specifically, severability clauses are viewed as exhortations instructing courts as to what they should do when finding the legislature's binding rules unconstitutional. Given their understanding of the question of severability as a matter of statutory construction, see supra note 3 , courts find these proclamations persuasive bases for decision.

However, a severability clause can alternatively be viewed as a binding directive establishing a form of "contingency legislation." Viewed from this perspective, the enacted statutory scheme directs the discriminatory allocation of benefits or burdens until a contingent event-here judicial invalidation of the discriminatory provision-occurs, at which time the severability clause directs a new nondiscriminatory allocation. Cf. Hampton \& Co. v. United States, 276 U.S. 394 (1928) (upholding statute whose operation was contingent upon Presidential policy determination). If seen as contingent legislation, the underlying statute's meaning changes as a matter of statutory construction at the moment a court declares it unconstitutional. Its "new" directives thus can be understood as springing into enactment after the court's invalidation of the discriminatory provision.

This provocative proposition generates a set of complex questions that deserve further inquiry. It must suffice here to observe that judicial rhetoric tends to support the characterization of severability clauses as non-binding exhortations. See, e.g., Dorchy v. Kansas, 264 U.S. 286, 290 (1924) (clause "provides a rule of construction which may sometimes aid in determining that intent. But it is an aid merely; not an inexorable command," even where clause expressly declares itself to establish a conclusive presumption); American Waterways Operators, Inc. v. Askew, 335 F. Supp. 1241, 1250 (M.D. Fla. 1971) (clause "is by no means binding on a court empowered to determine the constitutionality of a statute"). Even separately enacted statutes directing courts to save other statutes through severance wherever possible are viewed as non-binding exhortations. See, e.g., 2 J. SutherLand, STATUTORY Construction $\S 44.11$ (C. Sands 4th ed. 1972).

Yet, even if severability clauses are understood as contingency provisions and hence as working post-invalidation enactments of nondiscriminatory allocations, courts must still inquire into the legislative intent underlying their adoption in order to determine their proper effect. Where the enacting legislature's deliberations failed to satisfy the requisite conditions for an acceptable clear statement discussed supra at notes 84-86 and accompanying text, then courts should appeal to inchoate norms to set the remedial starting point for subsequent legislative review. The norm-based model is concerned with properly structured deliberation, not simply formally subsequent enactment.

88. The tasks of minimizing the institutional underenforcement of constitutional norms and defining the full scope of such norms are analytically independent. Though for both normative and expository reasons I have embraced a commitment to specific conceptions of particular norms, my argument primarily aims to persuade readers that whatever norms our Constitution is thought to embody, those norms ought to be enforced fully wherever possible. 
norms should encourage a more systemic inquiry into additional avenues for courts, consistent with a proper respect for competing structural values, to infuse these norms into law. ${ }^{89}$

89. Reducing norm underenforcement requires reexamination of both doctrinal right construction and remediation. For a provocative indictment of the former, see Note, Judicial Right Declaration and Entrenched Discrimination, 94 YALE L.J. 1741 (1985) (where broad remedial decrees necessary to remedy fully entrenched de jure segregation are infeasible because of high social costs and political backlash, courts should articulate full scope of doctrinal right even if forced to implement truncated remedy; candidly declaring right-remedy gap will promote greater actualization of right over time by inspiring victims' political action and by setting precedent for broader judicial remedies in future).

This focus on the process of right declaration, Professor Sager's focus on the role of government actors other than federal courts in enforcing norms, see supra note 74 , and my focus on judicial remedies for invalid legislative acts represent complementary attempts to structure an adjudicatory process that comprehends the autonomous status of constitutional norms. 